\title{
Coronavirus and surgery
}

\author{
UA Khan · MA Gok
}

Received: 15 May 2020 / Accepted: 12 June 2020 / Published online: 7 July 2020

(c) Springer-Verlag GmbH Austria, part of Springer Nature 2020

The coronavirus pandemic has changed our world for the foreseeable future. All countries throughout the world are struggling to cope with the devastating effects of the pandemic, both on human life and also on economics. As far as health systems all over the world are concerned, there have also been devastating effects. All routine operations have been cancelled. All endoscopies - whether for cancer diagnosis or surveillance-have been postponed for the foreseeable future.

Accident and emergency (A \& E) department attendances have fallen significantly since the COVID19 lockdown in Britain. The recorded drop prompted the Royal College of Emergency Medicine to advice the public not to be frightened of going to the A \& E. The figures from the Emergency Department Syndromic Surveillance System for England showed 89,584 attendances in the week after the lockdown was announced on March 23, 2020, a 25\% drop on 120,356 in the previous week [1].

Another problem is the shortage of personal protective equipment (PPE) world over. Doctors, nurses, carers and other healthcare workers are working under considerable constraints.

Royal colleges, surgical associations and Public Health England (PHE) have been working together to produce the most sensible and safe guidance. Here we look at the treatments that must continue, treatments which can be put on hold and also the uses of PPE.

\footnotetext{
U. Khan $(\bowtie) \cdot$ M. Gok

Macclesfield District General Hospital, East Cheshire NHS

Trust, Victoria Road, Macclesfield, East Cheshire, SK10

3BL, England, UK

usman.khan2@nhs.net

M. Gok

muhammed.gok@nhs.net
}

Essential and urgent cancer treatments must continue [2]. Cancer specialists should discuss with their patients whether it is riskier for them to undergo or to delay treatment at this time. Urgent consideration should be given to consolidating cancer surgery in a COVID-free hub, with centralised triage to prioritise patients based on clinical need. Patients over 70 are at an increased risk, and also those over 65 with chronic respiratory diseases such as moderate to severe asthma, COPD, emphysema, bronchitis, chronic heart disease, chronic kidney disease, hepatitis, and chronic neurological diseases such as motor neuron disease, multiple sclerosis, etc. [3]. Pregnant woman up to 28 weeks are also at a high risk, and so are diabetics and immunocompromised patients [3].

National guidance in the UK (23 March, 2020) proposed a system of prioritisation for cancer patients requiring surgery (Table $1 ;[2,4]$ ). Priority level 1a are emergency operations needed within $24 \mathrm{~h}$ to save lives, whereas priority level $1 \mathrm{~b}$ are urgent operations needed with $72 \mathrm{~h}$. Priority level 2 consists of elective surgery/treatment with the expectation of cure needed within 4 weeks to save life/stop progression, taking into account symptoms and potential complications from lack of treatment. Priority level 3 is elective surgery that can be delayed for 10 to 12 weeks and will have no predicted negative outcome. All elective surgery such as gall bladder, hernia, etc. as well as diagnostic colonoscopies can be put on hold.

The guidance regarding the use of PPE in common general surgical settings including the ward, admission area, endoscopy and operating theatre has also evolved with time [5].

We must consider the possibility of COVID-19 infection in every patient, follow national guidelines and apply common sense to at-risk clinical environments. Unfortunately, many patients will be disadvantaged by the current pandemic and increased risks apply to all 
Table 1 Emergency surgery within $24 \mathrm{~h}$

\begin{tabular}{|c|c|c|c|c|c|c|c|c|}
\hline $\begin{array}{l}\text { General } \\
\text { surgery (oe- } \\
\text { sophagogas- } \\
\text { tric, HPB, } \\
\text { coloproctol- } \\
\text { ogy, breast, } \\
\text { endocrine) }\end{array}$ & $\begin{array}{l}\text { Emergency } \\
\text { laparotomy } \\
\text { (peritonitis/ } \\
\text { perforation/ } \\
\text { ischaemia/ } \\
\text { necrotising } \\
\text { fasciitis) }\end{array}$ & $\begin{array}{l}\text { Emergency } \\
\text { laparo- } \\
\text { tomy- } \\
\text { bleeding not } \\
\text { responding to } \\
\text { endoscopic/ } \\
\text { interventional } \\
\text { radiology }\end{array}$ & $\begin{array}{l}\text { Appendicectomy- } \\
\text { complicated/ } \\
\text { unresponsive to } \\
\text { conservative Rx } \\
\text { appendicitis }\end{array}$ & $\begin{array}{l}\text { Intra-abdominal } \\
\text { trauma which } \\
\text { cannot be } \\
\text { managed } \\
\text { conservatively }\end{array}$ & $\begin{array}{l}\text { Laparotomy for } \\
\text { postoperative } \\
\text { complications } \\
\text { (e.g., anasto- } \\
\text { motic leaks/ } \\
\text { bleeding) }\end{array}$ & $\begin{array}{l}\text { Drainage of localised } \\
\text { sepsis/necrosis if not } \\
\text { responding to conser- } \\
\text { vative Rx (antibiotics/ } \\
\text { interventional radiol- } \\
\text { ogy) }\end{array}$ & $\begin{array}{l}\text { Benign } \\
\text { perforated } \\
\text { oesophagus/ } \\
\text { stomach- } \\
\text { with sur- } \\
\text { vivable me- } \\
\text { diastinitis/ } \\
\text { peritonitis }\end{array}$ & $\begin{array}{l}\text { Acute } \\
\text { airway ob- } \\
\text { struction- } \\
\text { thyroid }\end{array}$ \\
\hline
\end{tabular}

patients. Teams may have to apply judgement based on local circumstances, resources and for some exceptional patients. The possibility of COVID-19 should be sought in any patient referred acutely or needing emergency surgery; history, COVID-19 testing and CXR (chest X ray) can assist. Any patient undergoing an abdominal CT (computed tomography) scan for acute pain as an emergency presentation should have a chest CT at the same time, unless chest CT has previously been performed within $24 \mathrm{~h}$. Current tests for COVID-19, including CXR and chest CT, may be false negative. Any patient prioritised to undergo urgent planned surgery should self-isolate and be assessed for COVID-19 as above. The current greater risks of adverse outcomes from possible COVID-19 infection after surgery should be factored into planning and consent. Consider stoma formation rather than anastomosis to reduce the need for unplanned postoperative critical care for complications.

Operating theatres where aerosol-generating procedures (AGPs) are regularly performed are considered a higher risk clinical area and full PPE is advised where COVID-19 is possible or confirmed. General anaesthesia is an AGP. In line with PHE guidance, full PPE consists of disposable gloves and a fluid-repellent gown, eye/face protection and FFP2/3 (filtering face piece) mask. It is imperative to practise sterile donning and doffing of PPE in advance. Procedural tasks are slower and more difficult when wearing full PPE.

Laparoscopy is considered to carry some risks of aerosol-type formation and infection, and considerable caution is advised. The level of risk has not been clearly defined and the level of PPE deployed may be important. Advocated safety mechanisms (filters, traps, careful deflating) can be difficult to implement. The smoke plume at laparotomy from coagulating instruments may also not be without some risk. Given the current requirement to protect staff and other patients, a safety-first approach is needed.

Where nonoperative management is possible and reasonable (such as for early appendicitis and acute cholecystitis), this should be implemented. Appropriate nonoperative treatment of appendicitis and open appendicectomy offer alternatives. Some gall bladder operations can be reasonably deferred for several weeks.

In the operating room, the movement of staff should be minimized, with appropriate PPE for all staff in theatre depending on role and risk. All higher- risk patients should be intubated and extubated in theatre.

As far as endoscopy is concerned, only emergency endoscopic procedures should be performed. Routine diagnostic work should be avoided and British Society of Gastroenterology (BSG) guidance followed for urgent cases. Upper gastrointestinal procedures are high-risk AGPs and full PPE must be used.

We must consider the diagnosis and risk of COVID19 in other situations in emergency general surgery settings, and act and use PPE accordingly. Presentations with intestinal symptoms occur and COVID19 may present initially as an apparent postoperative complication. Nasogastric tube placement may be an AGP. Also, although chest compressions with cardiopulmonary resuscitation (CPR) are not normally considered aerosol generating, compression patients often splutter and cough, so full PPE in these instances should also be considered. AGPs are high risk and full PPE is needed. Consider carrying out in a specified location [6].

Medical care is now increasingly being carried out in a "virtual manner", short of patient exposure. Surgical practice has changed for the foreseeable future because of the COVID-19 pandemic. Surgical colleagues must take all precautions during ward rounds and operating procedures where they are in direct contact with the patient. Most multidisciplinary (MDT) meetings and other patient-related and management meetings are now being conducted virtually, which will probably become the norm in the future National Health Service.

Conflict of interest U. Khan and M. Gok declare that they have no competing interests.

\section{References}

1. Thornton J. Covid-19: A\&E visits in England fall by $25 \%$ in week after lockdown. BMJ. 2020;369:m1401.

2. NHS England aNIC. Advice to Trusts on maintaining cancer treatment during the COVID-19 response. 2020. https://www.england.nhs.uk/coronavirus/wp-content/ uploads/sites/52/2020/03/C0119-_Maintaining-cancerservices-_-letter-to-trusts.pdf

3. AUGIS. Updated general surgery guidance on COVID19. 2020. https://www.augis.org/wp-content/uploads/ 2020/04/2nd-Update-Intercollegiate-General-SurgeryGuidance-on-COVID-19-6-April-.._.pdf 
4. Academy of Medical Royal Colleges. Clinical guide for the management of essential cancer surgery for adults during the coronavirus pandemic. 2020. https://www.england. nhs.uk/coronavirus/wp-content/uploads/sites/52/2020/ 04/second-phase- of-nhs-response-to- covid-19-letterto-chief-execs-29-april-2020.pdf

5. Public Health England. Guidance: COVID-19 personal protective equipment (PPE). 2020. https://www.gov.uk/ government/publications/wuhan-novel-coronavirusinfection-prevention-and-control/covid-19-personalprotective-equipment-ppe
6. Royal College of Surgeons of Edinburgh. Updated general surgery guidance on COVID-19, 2nd revision, 7th April 2020. https://www.rcsed.ac.uk/news-public-affairs/ news/2020/april/updated-general-surgery-guidanceon-covid-19-2nd-revision-7th-april-2020

Publisher's Note Springer Nature remains neutral with regard to jurisdictional claims in published maps and institutional affiliations. 